Annals of Warsaw University of Life Sciences - SGGW

Land Reclamation No 47 (1), 2015: 43-54

(Ann. Warsaw Univ. Life Sci. - SGGW, Land Reclam. 47 (1), 2015)

\title{
Particulate matter in indoor spaces: known facts and the knowledge gaps*
}

\author{
PATRYCJA ROGULA-KOPIEC ${ }^{1}$, JÓZEF S. PASTUSZKA², \\ WIOLETTA ROGULA-KOZLOWSKA ${ }^{1}$, GRZEGORZ MAJEWSKI ${ }^{3}$ \\ ${ }^{1}$ Institute of Environmental Engineering, Polish Academy of Sciences \\ ${ }^{2}$ Department of Air Protection, Silesian University of Technology \\ ${ }^{3}$ Faculty of Civil and Environmental Engineering, Warsaw University of Life Sciences - SGGW
}

\begin{abstract}
Particulate matter in indoor spaces: known facts and the knowledge gaps. As people spend most of the time in closed spaces (flats, workplaces, schools etc.), the indoor air has been researched for many years all over the world. Particulate matter (PM) is one of the most often examined pollutants in the indoor and outdoor air. The following study presents the facts about PM in closed spaces and the most often taken actions. The least known aspects related to the indoor air pollution with PM are demonstrated. The indoor space of various service and office buildings/facilities (not related to production, i.e. offices, shops, beauty parlours, restaurant kitchens, restaurants, pubs etc.) seem to be an unrecognized area in the air pollution studies. Importantly, a great number of people work in such spaces all over the world and thus spend there a large part of their lives.
\end{abstract}

Key words: indoor aerosol, buildings, flats, sources of dust emissions, resuspension

\section{INTRODUCTION}

Atmospheric aerosol (an acronym for the atmospheric aerosol used in the literature is PM - particulate matter) can be investigated in terms of its chemical compo- sition, the ability to absorb and scatter light, the affinity to various chemical compounds, but the critical feature of the particles constituting the dispersed phase is their size (Hinds 1998). In the atmospheric air in every selected point of observation particles with aerodynamic diameters in the range from $10^{-3}$ to $100 \mu \mathrm{m}$ can be found. The fraction of particles of the specific sizes (range of diameters - $\mathrm{PM}_{1}, \mathrm{PM}_{2.5}, \mathrm{PM}_{10}$ are examined mostly, which means particles with aerodynamic diameter not greater than $1,2.5$ and $10 \mu \mathrm{m}$, respectively) in the given place depends on a large number of factors, including the origin of the particles (Whitby 1978). On the other hand, the main factor determining the deposition of inhaled particle in the respiratory tract is its aerodynamic diameter. Fine particles, belonging to the respirable fraction $\left(\mathrm{PM}_{1}\right.$ or $\left.\mathrm{PM}_{2.5}\right)$, are able to reach the deepest areas of lungs what makes their effects on human health much more serious than the effects of coarse particles

\footnotetext{
* The work was realized within the project DEC-2013/09/N/ST10/04224 financed by the National Science Centre Poland (NCN).
} 
(Englert 2004, Wichmann 2004, Ostro et al. 2007, Zhang et al. 2011).

The origin of PM also determines its chemical composition. Generally, the chemical substances, constituting almost the entire mass of PM in urbanized regions, can be divided into six groups (Chow 1995, Sillanpää et al. 2006, Rogula and Klejnowski 2013, Rogula-Kozłowska et al. 2014): geological matter (oxides of aluminum, silicon, calcium, titanium and iron), organic carbon (hundreds of compounds), elemental carbon, sulfates, nitrates and ammonia. In the regions that are industrialized and exposed to the effects of traffic emission the atmospheric aerosol also contains trace elements (Schroeder et al. 1987, Pastuszka et al. 2010). When the relative humidity of air is higher than $70 \%$, water is absorbed by soluble compounds and becomes a component of the aerosol. In coastal regions also water-soluble salts of sodium and chlorides are absorbed (Chow 1995, Sillanpää et al. 2006). In the areas where fossil fuels are the main sources of energy, sodium and chlorides originate from the combustion processes, what is particularly pronounced in the heating season (Rogula-Kozłowska et al. 2014).

The most common anthropogenic sources of dust include: industrial processes, energy production, transport and household emissions. Among the natural sources, the ones deserving special attention include: volcanic eruptions, resuspension of dust from soil and desert areas, marine aerosol, forest and steppe fires (Chow 1995, Hinds 1998). On a global scale the majority of PM in the atmosphere is of a natural origin. In urbanized areas natural sources have smaller contribution to the dust emission than the anthropogenic ones (Sówka et al. 2012, Majewski and Ćwiek 2013, Rogula-Kozłowska et al. 2013).

\section{BRIEF OVERVIEW OF THE INFORMATION ON PARTICULATE MATTER IN INDOOR AIR}

Particulate matter in indoor spaces may originate from both outdoor and indoor sources. The most significant indoor sources of aerosol include: tobacco smoking, combustion heating devices (burning of coal, wood, biomass), food preparation, building materials cleaning agents, different kinds of habitation-related activities. Bioaerosol particles (mainly bacteria) can be emitted indoors from human (as well as from pets) respiratory tract, skin and hair, as well from the plants present in the indoor environment.

In Table 1 the most important sources of indoor aerosol taken from Lippman (2009) are listed together with the methods recommended for reducing emission from these sources.

The atmospheric air can be considered as a substantial source of suspended dust for the closed spaces. Correlations between concentrations in the atmospheric air and in the closed spaces are interfered by the existence of indoor sources and different ventilation conditions (Monn 2001). In the summer concentrations of total suspended particulates in closed spaces are higher than in the winter. The influence of outdoor PM concentrations on the concentrations in 
TABLE 1. Indoor sources of aerosol (adapted from Lippman 2009)

\begin{tabular}{|c|c|}
\hline Category / Common sources & Mitigation and control \\
\hline \multicolumn{2}{|c|}{ Housekeeping and Maintenance } \\
\hline Cleanser & Use low-emitting products \\
\hline Waxes and polishes & Avoid aerosols and sprays \\
\hline Disinfectants & Dilute to proper strength \\
\hline Air fresheners & Do not overuse; use during unoccupied hours \\
\hline Adhesives & Use proper protocol when diluting and mixing \\
\hline Janitor's/storage closets & Store properly with containers closed and lid tight \\
\hline Wet mops & $\begin{array}{l}\text { Use exhaust ventilation for storage spaces (eliminate } \\
\text { return air) }\end{array}$ \\
\hline Drain cleaners & Clean mops, store mop top up to dry \\
\hline Vacuuming & Avoid "air fresheners" - clean and exhaust instead \\
\hline Paints and coatings & Use high-efficiency vacuum bags/filters \\
\hline Solvents & Use integrated pest management \\
\hline Pesticides & - \\
\hline Lubricants & - \\
\hline \multicolumn{2}{|c|}{ Occupant-related sources } \\
\hline Tobacco products & Smoking policy \\
\hline Office equipment (printers/copiers) & $\begin{array}{l}\text { Use exhaust ventilation with pressure control for ma- } \\
\text { jor local sources }\end{array}$ \\
\hline Cooking/microwave & Low-emitting art supplies/marking pens \\
\hline Art supplies & Avoid paper clutter \\
\hline Marking pens & Education material for occupants and staff \\
\hline Paper products (e.g. perfume) & - \\
\hline Tracked-in dirt/pollen & - \\
\hline \multicolumn{2}{|c|}{ Building uses as major sources } \\
\hline Print/photocopy shop & Use exhaust ventilation and pressure control \\
\hline Dry cleaning & $\begin{array}{l}\text { Use exhaust hoods where appropriate; check hood } \\
\text { airflows }\end{array}$ \\
\hline Science laboratory & - \\
\hline Medical office & - \\
\hline Hair/nail salon & - \\
\hline Cafeteria & - \\
\hline Pet store & - \\
\hline \multicolumn{2}{|c|}{ Building-related sources } \\
\hline Plywood/compressed wood & Use low-emitting sources \\
\hline Construction adhesives & Air out in an open/ventilated area before installing \\
\hline Asbestos products & Increase ventilation rates during and after installing \\
\hline Insulation & Keep material dry prior to enclosing \\
\hline Wall/floor coverings (vinyl/plastic) & 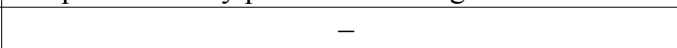 \\
\hline Carpets/carpet adhesives & - \\
\hline Wet building products & - \\
\hline Transformers & - \\
\hline Upholstered furniture & - \\
\hline Renovation/remodeling & - \\
\hline
\end{tabular}


TABLE 1 (continued)

\begin{tabular}{|l|l|}
\hline Category / Common sources & Mitigation and control \\
\hline Contaminated filters & PVAS system \\
\hline Contaminated duct lining & Change filter \\
\hline Dirty drain pans & Clean grain pans; proper slope and drainage \\
\hline Humidifiers & Use portable water for humidification \\
\hline Lubricants & $\begin{array}{l}\text { Keep duct lining dry; move lining outside of duct if } \\
\text { possible }\end{array}$ \\
\hline Refrigerants & Fix leaks/clean spills \\
\hline Mechanical room & $\begin{array}{l}\text { Maintain spotless mechanical room (not a storage } \\
\text { area) }\end{array}$ \\
\hline Maintenance activities & Avoid back drafting \\
\hline $\begin{array}{l}\text { Combustion appliances } \\
\text { (boilers/furnaces/stoves/generators) }\end{array}$ & Check/maintain flues from boiler to outside \\
\hline Mold & Moisture \\
\hline & Keep building dry \\
\hline & Vehicles \\
\hline Underground/attached garage & $\begin{array}{l}\text { Use exhaust ventilation } \\
\text { Maintain garage under negative pressure relative to } \\
\text { the building } \\
\text { Check airflow patterns frequently } \\
\text { Monitor carbon monoxide }\end{array}$ \\
\hline
\end{tabular}

closed spaces is characterized by the I/O ratio (indoor / outdoor) of the PM concentration in a closed space to the concentration in the atmospheric air.

The I/O ratio for various fraction of PM can lie within the range from 0.1 to 31.4. $\mathrm{PM}_{2.5}$, I/O ratios in the large-scale studies (larger than 20 homes) in different cites are in the range between 0.8 and 3.4 (Chen and Zhao 2011). Values of the $\mathrm{I} / \mathrm{O}$ ratio for $\mathrm{PM}_{10}$, encountered in the literature are in the range between 1.14 and 3.91 (Morawska and Salthammer 2006). In air-conditioned spaces where dust filters are used this ratio can be low, between 0.1 and 0.3 (Yocom 1982).

Although in a given area atmospheric PM can constitute a relatively steady (in terms of concentration) background for particular houses, the indoor PM concentrations in this region can vary for the different buildings and spaces. The dispersed fraction of the atmospheric aerosol can have a contribution to the concentration of suspended dust in the air of closed spaces reaching $70 \%$ for naturally ventilated spaces and $30 \%$ for spaces with air conditioning (Dockery and Spengler 1981). In houses with no substantial indoor sources of emission the atmospheric air contributes $75 \%$ to the $\mathrm{PM}_{2.5}$ and $66 \%$ to the $\mathrm{PM}_{10}$ indoor concentration (Özkaynak et al. 1996). In houses with substantial indoor sources of dust (cooking, tobacco smoking) atmospheric air can contribute about $55-60 \%$ to the indoor $\mathrm{PM}_{10}$ and $\mathrm{PM}_{2.5}$ concentrations. 
Cigarette smoking is a very effective source of particles suspended in the air in closed spaces. The I/O ratio of the indoor dust concentration to the concentration in atmospheric air for spaces in which tobacco is smoked is greater than unity, e.g. generally $\mathrm{I} / \mathrm{O}$ for $\mathrm{PM}$ in spaces where tobacco is smoked can reach $2.7 \pm 6.7$ and for $\mathrm{PM}_{10}$ it can be between $1.8 \pm 0.9$ (May) and $2.9 \pm 3.0$ (September) in a rural area, and 3.9 \pm 7.8 (March) in an urban flat (Jones et al. 2000), while in the case of spaces where tobacco is not smoked the ratio is equal to unity (Monn 2001). Mean 48-hour indoor concentration of $\mathrm{PM}_{2.5}$ (in the winter) can increase by $33 \mu \mathrm{g} / \mathrm{m}^{3}$ under the influence of cigarette smoking (Simoni et al. 1998), 24-hour concentration can rise by $25-32 \mu \mathrm{g} / \mathrm{m}^{3}$, and 12-hour concentration by 30 $-35 \mu \mathrm{g} / \mathrm{m}^{3}$ (Özkaynak et al. 1996).

The use of gas stoves (cooking) causes a significant increase in the $\mathrm{I} / \mathrm{O}$ ratio only during meal preparation (Jones et al. 2000).

Also cleaning with the use of vacuum cleaners and wood burning (in fireplaces) are substantial sources of solid particles in the air of closed spaces (Monn 2001).

Human activity alone is an important factor affecting the concentration levels of dust particles in closed spaces. Activities performed by users of the spaces, their movement, cause continuous movement of dust particles present in the spaces: suspending, mixing in the air, re-settling. These phenomena contribute to the increase in concentrations of particles with the aerodynamic diameter smaller than $2.5 \mu \mathrm{m}$. They cause a rise in the $\mathrm{I} / \mathrm{O}$ ratio, and although not in every case (Jones et al. 2000) in one of the houses no relationship between the rise in mean $\mathrm{PM}_{10}$ concentrations and movement of people was found), but in (Jones et al. 2000) in the majority of cases, an increase in the $\mathrm{PM}_{10}$ mean concentration from 10 to $40 \mu \mathrm{g} / \mathrm{m}^{3}$ caused by the movement of residents was observed.

In the environments of closed spaces occupied by people and animals usually dust particles of animal origin are present in the air (from acari, insects, dogs, cats, birds etc.).

It should not go unmentioned that, apart from suspended dust, indoor sources also emit other pollutants. The most important groups of indoor pollutants and their sources are given in Table 2.

Air inside accommodation spaces ( Table 3), spaces in public utility buildings (schools, kindergartens, theatres, hospitals, museums, library; Table 4), and inside public transport vehicles as well as the relationships between indoor and outdoor sources of dust and gaseous pollutants and air quality have already been studied quite thoroughly (Dockery and Spengler 1981, Yocom 1982, Lis and Pastuszka 1997, Levy et al. 1998, Simoni et al. 1998, Pastuszka et al. 1998, 2000, 2005, Godish, 2000, Long et al. 2000, Li and Lin 2003, Morawska and Salthammer 2006, Colbeck et al. 2010, Dudzińska 2011, Lioy et al. 2011, Gurley et al. 2013, Zwoździak et al. 2013, Célia et al. 2014, Pollard et al. 2014). 
TABLE 2. The most important groups of pollutants emitted from selected indoor sources (adapted from Lippman 2009)

\begin{tabular}{|l|l|}
\hline Pollutant or Pollutant class & \multicolumn{1}{|c|}{ Potential sources } \\
\hline Combustion contaminants & $\begin{array}{l}\text { furnaces, generators, gas or kerosene space heaters, tobacco prod- } \\
\text { ucts, outdoor air, vehicles }\end{array}$ \\
\hline Biological contaminants & $\begin{array}{l}\text { wet or damp materials, cooling towers, humidifiers, cooling coils } \\
\text { or drain pans, damp duct insulation of filters, condensation, re-en- } \\
\text { trained sanitary exhausts, bird droppings, cockroaches or rodents, } \\
\text { dust mites on upholstered furniture or carpeting, body odors }\end{array}$ \\
\hline $\begin{array}{l}\text { Volatile organic compounds } \\
\text { (VOCs) }\end{array}$ & $\begin{array}{l}\text { paints, stains, varnishes, solvents, pesticides, adhesives, wood pre- } \\
\text { servatives, waxes, polishes, cleansers, lubricants, sealants, dyes, air } \\
\text { fresheners, fuels, plastics, copy machines, printers, tobacco prod- } \\
\text { ucts, perfumes, dry cleaned clothing }\end{array}$ \\
\hline Formaldehyde & particleboard, plywood, cabinetry, furniture, fabrics \\
\hline $\begin{array}{l}\text { Soil gases (radon, sewer gas, } \\
\text { VOCs, drain leak, drain methane) }\end{array}$ & $\begin{array}{l}\text { soil and rock (radon), sewer traps, leaking underground storage } \\
\text { tanks, landfill }\end{array}$ \\
\hline Pesticides & $\begin{array}{l}\text { termiticides, insecticides, rodenticides, fungicides, disinfectants, } \\
\text { herbicides }\end{array}$ \\
\hline
\end{tabular}

TABLE 3. Comparison of $\mathrm{PM}_{1}$ and $\mathrm{PM}_{2.5}$ concentrations in ambient (outdoor) and indoor (accommodation spaces) air (mean \pm standard deviation)

\begin{tabular}{|c|c|c|}
\hline \multirow{2}{*}{ Site } & \multicolumn{2}{|c|}{ PM concentration $\left(\mu \mathrm{g} / \mathrm{m}^{3}\right)$} \\
\hline & indoor & outdoor \\
\hline${ }^{\mathrm{a}}$ Hong Kong $\left(\mathrm{PM}_{2.5}\right)$ & 50.4 & - \\
\hline${ }^{\text {a }}$ Southern California $\left(\mathrm{PM}_{2.5}\right)$ & 15.45 & 15.2 \\
\hline \multirow{2}{*}{ Birmingham $\left(\mathrm{PM}_{2.5}\right)$} & summer $16.1 \pm 5.7$ & summer $26.5 \pm 9.5$ \\
\hline & winter $11.2 \pm 5.4$ & winter $12.2 \pm 5.1$ \\
\hline${ }^{\mathrm{a}}$ Athens $\left(\mathrm{PM}_{2.5}\right)$ & $35.6 \pm 29.4$ & $37.3 \pm 27.4$ \\
\hline${ }^{\mathrm{a}}$ Basel $\left(\mathrm{PM}_{2.5}\right)$ & $21.0 \pm 16.7$ & $19.3 \pm 11.5$ \\
\hline${ }^{\mathrm{a}}$ Helsinki $\left(\mathrm{PM}_{2.5}\right)$ & $9.5 \pm 6.1$ & $10.5 \pm 7.1$ \\
\hline${ }^{\text {a }}$ Prague $\left(\mathrm{PM}_{2.5}\right)$ & $34.4 \pm 28.7$ & $27.3 \pm 10.4$ \\
\hline${ }^{a}$ Birmingham $\left(\mathrm{PM}_{1}\right)$ & $9.9 \pm 3.3$ & $8.3 \pm 4.1$ \\
\hline \multirow{2}{*}{${ }^{\text {a }}$ Taipei $\left(\mathrm{PM}_{1}\right)$} & summer $25.4 \pm 8.9$ & summer $28.8 \pm 9.8$ \\
\hline & winter $26.4 \pm 14.1$ & winter $27.0 \pm 14.4$ \\
\hline \multirow{2}{*}{${ }^{\mathrm{a}}$ Taipei $\left(\mathrm{PM}_{2.5}\right)$} & summer $36.6 \pm 12.6$ & summer $36.3 \pm 12.7$ \\
\hline & winter $38.7 \pm 19.5$ & winter $38.3 \pm 20.7$ \\
\hline${ }^{\mathrm{b}}$ Katowice $\left(\mathrm{TSP}^{\mathrm{c}}\right)$ & 100 & 156 \\
\hline${ }^{\mathrm{b}}$ Katowice (fine PM) & 69 & 59 \\
\hline${ }^{\mathrm{b}}$ Bytom $\left(\mathrm{TSP}^{\mathrm{c}}\right)$ & 102 & 289 \\
\hline b Bytom (fine PM) & 72 & 105 \\
\hline${ }^{\mathrm{b}}$ Sosnowiec $\left(\mathrm{TSP}^{\mathrm{c}}\right)$ & 82 & 213 \\
\hline b Sosnowiec (fine PM) & 74 & 50 \\
\hline${ }^{\mathrm{b}}$ Chorzów $\left(\mathrm{TSP}^{\mathrm{c}}\right.$ ) & 93 & 405 \\
\hline${ }^{\mathrm{b}}$ Chorzów (fine PM) & 81 & 124 \\
\hline
\end{tabular}

${ }^{\mathrm{a}} \mathrm{Li}$ and Lin 2003; ${ }^{\mathrm{b}}$ Górny et al. $1995 ;{ }^{\mathrm{c}} \mathrm{TSP}$ - total suspended particles (total PM). 
TABLE 4. Comparison of PM concentrations in ambient (outdoor) and air in some public utility buildings (indoor)

\begin{tabular}{|c|c|c|c|}
\hline \multirow{2}{*}{ Site } & \multicolumn{3}{|c|}{ PM concentration $\left(\mu \mathrm{g} / \mathrm{m}^{3}\right)$} \\
\hline & \multicolumn{2}{|c|}{ indoor } & outdoor \\
\hline $\begin{array}{l}\text { a School in Wrocław } \\
\text { Summer } \\
\mathrm{PM}_{1} \\
\mathrm{PM}_{2.5} \\
\mathrm{PM}_{10} \\
\text { Winter } \\
\mathrm{PM}_{1} \\
\mathrm{PM}_{2.5} \\
\mathrm{PM}_{10}\end{array}$ & & & $\begin{array}{r}25.5 \pm 7.8 \\
49.1 \pm 15.6 \\
56.8 \pm 17.3\end{array}$ \\
\hline $\begin{array}{l}{ }^{\mathrm{b}} \text { Wawel Castle museum } \\
\text { Winter (TSP }{ }^{\mathrm{d}} \text { ) } \\
\text { Room } 1 \text { (ground floor) } \\
\text { Room } 2 \text { (1st floor) } \\
\text { Room } 3 \text { (2nd floor) } \\
\text { Summer (TSP }) \\
\text { Room } 1 \text { (ground floor) } \\
\text { Room } 2 \text { (1st floor) } \\
\text { Room } 3 \text { (2nd floor) }\end{array}$ & \multicolumn{2}{|c|}{$\begin{array}{l}73 \pm 2 \\
79 \pm 2 \\
61 \pm 2\end{array}$} & $59 \pm 2$ \\
\hline $\begin{array}{l}\text { 'Classrooms in the 1st school } \\
\text { occupied; biology } \\
\mathrm{PM}_{1} \\
\mathrm{PM}_{2.5} \\
\mathrm{PM}_{10} \\
\mathrm{TSP} \\
\text { occupied; physic } \\
\mathrm{PM}_{1} \\
\mathrm{PM}_{2.5} \\
\mathrm{PM}_{10} \\
\mathrm{TSP} \\
\text { vacant; biology } \\
\mathrm{PM}_{1} \\
\mathrm{PM}_{2.5} \\
\mathrm{PM}_{10} \\
\mathrm{TSP} \\
\text { vacant; physic } \\
\mathrm{PM}_{1} \\
\mathrm{PM}_{2.5} \\
\mathrm{PM}_{10} \\
\mathrm{TSP}\end{array}$ & $\begin{array}{r}\text { winter } \\
47 \\
48 \\
105 \\
297 \\
\\
118 \\
119 \\
191 \\
363 \\
\\
22 \\
23 \\
39 \\
59 \\
\\
61 \\
62 \\
72 \\
85\end{array}$ & $\begin{array}{r}\text { summer } \\
59 \\
60 \\
78 \\
132 \\
\\
78 \\
78 \\
104 \\
192 \\
\\
34 \\
34 \\
48 \\
87 \\
52 \\
52 \\
62 \\
82\end{array}$ & - \\
\hline
\end{tabular}

${ }^{\mathrm{a}}$ Zwoździak et al. 2013, ${ }^{\mathrm{b}}$ Worobiec et al. 2010, ${ }^{\mathrm{c}}$ Połednik 2013; ${ }^{\mathrm{d}} \mathrm{TSP}-$ total suspended particles (total PM). 
GAPS IN THE CURRENT STATE OF KNOWLEDGE

It appears that non-production spaces, i.e. offices, photocopy shops, kitchens, restaurants, hair salons, beauty parlours, etc., are the most poorly characterized in this regard. On one hand, they constitute the most common workplaces door sources (e.g. from secondary emission of settled dust) - Table 5 .

The changes in size distribution can be particularly significant in the case of hygroscopic dusts penetrating into spaces with high air humidity (e.g. kitchen rooms). The above mentioned phenomena were only partially characterized in

TABLE 5. Possible changes in the structure of the atmospheric aerosol in non-production spaces. Own analysis

\begin{tabular}{|l|l|c|}
\hline Mechanism of the changes & \multicolumn{1}{|c|}{ Examples of the spaces } & $\begin{array}{c}\text { Changes in aerosol } \\
\text { structure }\end{array}$ \\
\hline Condensation on particles & $\begin{array}{l}\text { beauty parlours, kitchens, photocopy } \\
\text { shops }\end{array}$ & a, b, d, e, f \\
\hline Nucleation & beauty parlours, kitchens & $\mathrm{a}, \mathrm{b}, \mathrm{c}, \mathrm{d}, \mathrm{e}, \mathrm{f}$ \\
\hline $\begin{array}{l}\text { Absorption of water vapour by } \\
\text { hygroscopic particles }\end{array}$ & kitchens & $\mathrm{a}, \mathrm{b}, \mathrm{d}, \mathrm{f}$ \\
\hline Gas adsorption on particles & $\begin{array}{l}\text { beauty parlours, kitchens, photocopy } \\
\text { shops, offices }\end{array}$ & $\mathrm{a}, \mathrm{b}, \mathrm{d}, \mathrm{e}, \mathrm{f}$ \\
\hline $\begin{array}{l}\text { Emission and re-emission of } \\
\text { dust }\end{array}$ & beauty parlours, kitchens, offices & $\mathrm{a}, \mathrm{b}, \mathrm{c}, \mathrm{d}, \mathrm{e}, \mathrm{f}$ \\
\hline
\end{tabular}

Designations: $\mathrm{a}$ - change of the morphology of the particles, $\mathrm{b}$ - change of the mass concentration, $\mathrm{c}$ - change of the number concentration, $\mathrm{d}$ - change of the size distribution, $\mathrm{e}$ - change of the chemical composition, $\mathrm{f}$ - change of the optical parameters.

nowadays in developed countries, and thus are the environment of prolonged residence for a vast number of people, while on the other hand they are an environment, completely different than the atmospheric air, in which mutual interactions of pollutants already present in the spaces with those migrating from the outdoor air takes place.

Migration of the atmospheric aerosol into indoor spaces may cause measurable changes in the level of concentrations and in the size distribution of dust particles, which will overlap with changes resulting from dust emission from out- a quantitative manner. For the majority of indoor spaces qualitative or semi-quantitative characterizations are predominant in the subject literature. It seems that this kind of changes should be expected particularly in an urbanized and highly industrialized area. Atmospheric aerosol in such areas contains a large proportion of elemental carbon (Rogula-Kozłowska et al. 2014), especially in the surface layer (Pastuszka et al., 2003, Klejnowski et al. 2012), what makes it particularly susceptible to adsorption of gaseous substances, such as volatile organic compounds (VOCs), polycyclic aromatic compounds (PAHs) 
or oxides of various metals. Processes of this type, consisting in the enrichment of aerosol particles in adsorbed gaseous pollutants, have not yet been studied in the indoor environment.

Research in this mainstream would allow to detect and describe general patterns in the evolution of the atmospheric aerosol, resulting from it being contacted with an indoor stream of gaseous pollutants, in relation to the characteristics of indoor emitters and parameters of the indoor environment, what would fill the gap in the current state of knowledge.

If the changes in aerosol structure in indoor spaces, that are to be the subject of the studies, turn out to be significant, there will be a necessity to modify the methods for prognosis health effects of exposure of the general population to the outdoor aerosol.

\section{REFERENCES}

ALVES C.A., URBAN R.C., PEGAS P.N., NUNES T. 2014. Indoor/Outdoor relationships between PM10 and associated organic compounds in a primary school. Aerosol and Air Quality Research 14 (1), 86-98.

CHEN C., ZHAO B. 2011: Review of relationship between indoor and outdoor particles: $\mathrm{I} / \mathrm{O}$ ratio, infiltration factor and penetration factor. Atmos. Environ. 45 (2), 275-288.

CHOW J.C. 1995: Measurement methods to determine compliance with ambient air quality standards for suspended particles. J. Air Waste Manage Assoc. 45, 320-382.

COLBECK I., NASIR Z.A., ALI Z. 2010: Characteristics of indoor/outdoor particulate pollution in urban and rural residential environment of Pakistan. Indoor Air 20 (1), 40-51.

DOCKERY D.W., SPENGLER J.D. 1981: Indoor-Outdoor Relationship of Respirable Sulfates and Particles. Atmos. Environ. 15, 335-343.
DUDZIŃSKA M.R. (Ed.) 2011: Management of Indoor Air Quality. Taylor \& Francis Group, London, CRC Press/Balkema.

ENGLERT N. 2004: Fine particles and human health - a review of epidemiological studies. Toxicol. Lett. 149, 235-242.

GÓRNY R., JĘDRZEJCZAK A., PASTUSZKA J.S. 1995: Airborne particles and heavy metals in upper Silesia outdoors and indoors. Roczn. PZH. XLVI (2), 151-161.

GODISH T. 2000: Indoor Environmental Quality. CRC Press, Boca Raton, 456.

GURLEY E.S., SALJE H., HOMAIRA N., RAM P.K., HAQUE R., PETRI W.A. ... AZZIZ-BAUMGARTNER E. 2013: Seasonal concentrations and determinants of indoor particulate matter in a low-income community in Dhaka, Bangladesh. Environ. Res. 121, 11-16.

HINDS W.C. 1998: Aerosol Technology. Properties, Behavior, and Measurement of Airborne Particles. Second Edition. John Wiley \& Sons, New York.

JONES N.C., THORNTON C.A., MARK D., HARRISON R.M. 2000: Indoor/Outdoor Relationships of Particulate Matter in Domestic Homes with Roadside, Urban and Rural Locations. Atmos. Environ. 34, 2603-2612.

KLEJNOWSKI K., PASTUSZKA J.S., ROGULA-KOZLOWSKA W., TALIK E., KRASA A. 2012: Mass Size Distribution and Chemical Composition of the Surface Layer of Summer and Winter Airborne Particles in Zabrze, Poland. Bull. Environ. Contam. Toxicol. 88 (2), 255-259.

LEVY J.I., LEE K., SPENGLER J.D., YANAGISAWA Y., BISHOF W., BRAATHEN O., CHUNG Y., COWARD S., GUTSCHMIDT K., JIN K., KORENAGA T., OHKODA Y., MENESES F., PASTUSZKA J., PATIL R.S., QUING X., RAIZENNE M., SALONEN R.O., SEGA K., SEIFERT B., SHAH S., TORRES E., YOON D., ZHANG X. 1998: Impact of residential nitrogen dioxide exposure on personal exposure: an international study. J. Air Waste Manage Assoc. 48, 553-560.

LI C.S., LIN C.H. 2003: Carbon Profile of Residential Indoor PM1 and PM2.5 in the Subtropical Region. Atmos. Environ. 37, 881-888. 
LIOY P.J., FAN Z, ZHANG J., GEORGOPOULOS P., WANG S.W., OHMAN-STRICKLAND P., WU X., ZHU X., HARRINGTON J., TANG X., MENG Q., JUNG K.H., KWON J., HERNANDEZ M., BONNANO L., HELD J., NEAL J. 2011: Personal and ambient exposures to air toxics in Camden, New Jersey. Res. Rep. Health Eff. Inst. 160, 3-127.

LIPPMAN M. 2009: Environmental Toxicants: Human Exposures and Their Health Effects. John Wiley \& Sons, New York, 987.

LIS D.O., PASTUSZKA J.S. 1997: Bacterial and fungal aerosol in homes without and with mold problem in Upper Silesia, Poland. Preliminary results. J. Aerosol Sci. 28, 665-666.

LONG C.M., SUH H.H., KOUTRAKIS P. 2000: Characterization of Indoor Particle Sources Using Continuous Mass and Size Monitors. J. Air Waste Manage Assoc. 50, 1236-1250.

MAJEWSKI G., ĆWIEK K. 2013: Effect of a different degree of anthropogenic trans-formation on the formation of bioclimatic conditions - Warsaw case study. Ann. Warsaw Univ. of Life Sci. - SGGW, Land Reclamation 45 (1), 97-109.

MONN C. 2001: Exposure Assessment of Air Pollutants: A Review on Spatial Heterogeneity and Indoor/Outdoor/Personal Exposure to Suspended Particulate Matter, Nitrogen, Dioxide and Ozone. Atmos. Environ. 35, 1-32.

MORAWSKA L., SALTHAMMER T. 2006: Indoor Environment. Airborne Particles and Settled Dust. John Wiley \& Sons, New York.

OSTRO B., FENG W.Y., BROADWIN R., GREEN S., LIPSETT M. 2007: The effects of components of fine particulate air pollution on mortality in California: results from CALFINE. Environ. Health Persp. 115, 13-19.

ÖZKAYNAK H., XUE J SPENGLER J., WALLACE L., PELLIZZARI E., JENKINS P. 1996: Personal Exposure to Airborne Particles and Metals: Results fro the Particle Team Study in Riverside, C.A. J. Expo. Sci. Environ. Epidemiol. 6, 57-78.

PASTUSZKA J.S., ZEJDA J.E., WLAZŁO A., LIS D.O., MALISZEWSKA I. 1998: Occurrence of bronchial asthmas symptoms in children, and the level of exposure to dust, bacterial and fungal aerosols in Sosnowiec apartments. Problemy Ekologii 5, 171-173.

PASTUSZKA J.S., MARCHWIŃSKA-WYRWAŁ E., WLAZŁO A. 2005: Bacterial aerosol in the Silesian hospitals: preliminary results. Pol. J. Environ. Studies 14, 883-890.

PASTUSZKA J.S., ROGULA-KOZŁOWSKA W., ZAJUSZ-ZUBEK E. 2010: Characterization of PM10 and PM2.5 and associated heavy metals at the crossroads and urban background site in Zabrze, Upper Silesia, Poland, during the smog episodes. Environ. Monit. Assess. 168, 613-627.

PASTUSZKA J.S., WAWROŚ A., TALIK E., PAW U.K.T. 2003: Optical and chemical characteristics of the atmospheric aerosol in four towns in southern Poland. Sci. Tot. Environ. 309, 237-251.

PASTUSZKA J.S., KYAW., THA PAW U., LIS D.O., WLAZŁO A., ULFIG K. 2000: Bacterial and fungal aerosol in indoor environment in Upper Silesia, Poland. Atmos. Environ. 34, 3833-3842.

POLEDNIK B. 2013: Particulate matter and student exposure in school classrooms in Lublin, Poland. Environ. Res. 120, 134-139.

POLLARD S.L., WILLIAMS D.L., BREYSSE P.N. 2014: A cross-sectional study of determinants of indoor environmental exposures in households with and without chronic exposure to biomass fuel smoke. Environ. Health $13(1), 21$.

ROGULA-KOZŁOWSKA W., BŁASZCZAK B., SZOPA S., KLEJNOWSKI K., SÓWKA I., ZWOŹDZIAK A., JABŁOŃSKA M., MATHEWS B. 2013: PM2.5 in the central part of Upper Silesia, Poland: concentrations, elemental composition, and mobility of components. Environ. Monit. Assess. 185, 581-601.

ROGULA-KOZŁOWSKA W., KLEJNOWSKI K., ROGULA-KOPIEC P., OŚRÓDKA L., KRAJNY E., BŁASZCZAK B, MATHEWS B. 2014: Spatial and seasonal variability of the mass concentration and chemical composition of PM2.5 in Poland. Air Qual. Atmos. Health. 7, 41-58.

ROGULA-KOZLOWSKA W., KLEJNOWSKI K. 2013: Submicrometer aerosol in rural and urban backgrounds in Southern Poland 
- primary and secondary components of PM1. Bull. Environ. Contam. Toxicol. 90 (1), 103-109.

SCHROEDER W.H., DOBSON M., KANE D.M., JOHNSON N.D. 1987: Toxic trace elements associated with airborne particulate matter: a review. J. Air Pollut. Control Assoc. 37, 1267-1285.

SILLANPÄÄ M., HILLAMO R., SAARIKOSKI S., FREY A., PENNANEN A., MAKKONEN U., SPOLNIK Z., VAN GRIEKEN R., BRANIŠ M., BRUNEKREEF B., CHALBOT M.C., KUHLBUSCH T., SUNYER J., KERMINEN V.M., KULMALA M., SALONEN R.O. 2006: Chemical composition and mass closure of particulate matter at six urban sites in Europe. Atmos. Environ. 40, 212-223.

SIMONI M., BIAVATTI P., CARROZZI L., VIEGI G., PAOLETTI P., MATTEUCCI G., ZILIANI G.L., IOANNILLI E., SAPIGNI T. 1998: Po Tiver Delta (North Italy) Indoor Epidemiological Study: Home Characteristics, Indoor Pollutants, And Subjects' Daily Activity Pattern. Indoor Air 8, 70-79.

SÓWKA I., ZWOŹDZIAK A., TRZEPLA-NABAGLO K., SKRĘTOWICZ M., ZWOŹDZIAK J. 2012: PM2.5 elemental composition and source apportionment in residential area of Wrocław, Poland. Environ. Prot. Eng. 38, 73-79.

WHITBY K.J. 1978: The Physical Characteristics of Sulfur Aerosol. Atmos. Environ. 12, 135-139.

WICHMANN H.E. 2004: Health effects of particles in ambient air. Int. J. Hyg. Environ. Heal. 207, 399-407.

WOROBIEC A., SAMEK L., KRATA A., Van MEEL K., KRUPINSKA B., STEFANIAK E.A., ... Van GRIEKEN R. 2010: Transport and deposition of airborne pollutants in exhibition areas located in historical buildings - study in Wawel Castle Museum in Cracow, Poland. Journal of Cultural Heritage 11 (3), 354-359.

YOCOM J.E. 1982: Indoor-Outdoor Air Quality Relationships. A Critical Review. J. Air Control Assoc. 32, 500-520.

ZHANG W., LEI T., LIN Z.Q., ZHANG H.S., YANG D.F., XI Z.G., CHEN J.H., WANG W.
2011: Pulmonary toxicity study in rats with PM10 and PM2.5: differential responses related to scale and composition. Atmos. Environ. 45, 1034-1041.

ZWOŹDZIAK A., SÓWKA I., KRUPIŃSKA B., ZWOŹDZIAK J., NYCH A. 2013: Infiltration or indoor sources as determinants of the elemental composition of particulate matter inside a school in Wrocław, Poland? Build. Environ. 66, 173-180.

Streszczenie: Pylzawieszony w pomieszczeniach: znane fakty i luki $w$ stanie wiedzy. Ponieważ większość życia ludzie spędzają w pomieszczeniach zamkniętych (mieszkania, miejsca pracy, szkoły, itp.), powietrze wewnętrzne jest od wielu lat przedmiotem zainteresowania grup badaczy na całym świecie. Jednym z najczęściej badanych zanieczyszczeń w powietrzu wewnętrznym jest, podobnie jak w powietrzu zewnętrznym, pył zawieszony, PM. W pracy przedstawiono udokumentowane fakty dotyczace PM w pomieszczeniach zamkniętych i najczęściej podejmowane kierunki działań w tym zakresie. Wskazano również obszar najsłabiej rozpoznany pod względem zanieczyszczenia powietrza pyłem zawieszonym. Przestrzeń wewnętrzna różnego rodzaju obiektów usługowo-biurowych (nieprodukcyjnych, tj. biura, sklepy, salony urody, kuchnie restauracyjne, restauracje, puby itp.) wydaje się być zupełnie nierozpoznanym obszarem jeżeli chodzi o zanieczyszczenie powietrza. Tymczasem, właśnie w takich obiektach pracuje i tym samym spędza dużą część swojego życia mnóstwo osób na całym świecie.

Słowa kluczowe: aerozol wewnętrzny, budynki, mieszkania, źródła emisji pyłu, resuspensja

\section{MS. received October 2014}

\section{Authors' addresses:}

Patrycja Rogula-Kopiec, Wioletta Rogula-Kozłowska Instytut Podstaw Inżynierii Środowiska PAN ul. M. Skłodowska-Curie 34, 41-819 Zabrze Poland e-mail: patrycja.rogula-kopiec@ipis.zabrze.pl; wioletta.rogula-kozlowska@ipis.zabrze.pl 
54 P. Rogula-Kopiec et al.

Józef S. Pastuszka

Politechnika Śląska

ul. Konarskiego 22B, 44-100 Gliwice

Poland

e-mail: jozef.pastuszka@polsl.pl

Grzegorz Majewski

Wydział Budownictwa i Inżynierii Środowiska

Katedra Inżynierii Wodnej SGGW

ul. Nowoursynowska 159, 02-776 Warszawa

Poland

e-mail: grzegorz_majewski@sggw.pl 